\title{
Review Article \\ Chest Computed Tomography Findings in COVID-19 and Influenza: A Narrative Review
}

\author{
Stephen O. Onigbinde $\mathbb{D}^{1},{ }^{1}$ Ademola S. Ojo $\mathbb{D}^{1},{ }^{1}$ Linwald Fleary, $^{2}$ and Robert Hage ${ }^{1}$ \\ ${ }^{1}$ Department of Anatomical Sciences, St. George's University School of Medicine, St. George's, West Indies, Grenada \\ ${ }^{2}$ Radiology, General Hospital, St. George's, West Indies, Grenada
}

Correspondence should be addressed to Stephen O. Onigbinde; sonigbin@sgu.edu

Received 23 April 2020; Revised 11 May 2020; Accepted 18 May 2020; Published 6 June 2020

Academic Editor: Nazario Carrabba

Copyright (C) 2020 Stephen O. Onigbinde et al. This is an open access article distributed under the Creative Commons Attribution License, which permits unrestricted use, distribution, and reproduction in any medium, provided the original work is properly cited.

Objective. The COVID-19 pandemic and annual influenza epidemic are responsible for thousands of deaths globally. With a similarity in clinical as well as laboratory findings, there is a need to differentiate these two conditions on chest CT scan. This paper attempts to use existing literature to draw out differences in chest CT findings in COVID-19 and influenza. Methods. A search was conducted using PubMed. 17 original studies on chest CT findings in COVID-19 and influenza were identified for full-text review and data analysis. Findings. COVID-19 and influenza share similar chest CT findings. The differences found show that COVID-19 ground-glass opacities are usually peripherally located with the lower lobes being commonly involved, while influenza has a central, peripheral, or random distribution usually affecting the five lobes. Vascular engorgement, pleural thickening, and subpleural lines were reported in COVID-19 patients. In contrast, pneumomediastinum and pneumothorax were reported only in studies on influenza. Conclusion and Relevance. COVID-19 and influenza have overlapping chest CT features with few differences which can assist in telling apart the two pathologies. Additional studies are needed to further define the differences and degree between COVID-19 and influenza.

\section{Introduction}

On December 31, 2019, the first report emerged of an outbreak of an acute respiratory infection of unknown origin in Wuhan, Hubei province of China. This highly contagious viral infection caused by the novel coronavirus (2019-nCoV or SARS-CoV-2) rapidly spread across the country $[1,2]$. By January 29, 2020, the number of confirmed cases had increased to 5997 in China with 132 deaths and 68 cases reported in 15 other countries [3]. The World Health Organization declared 2019-nCoV a global pandemic by March 12 . The virus rapidly swept through countries with $1,773,084$ confirmed cases and 111,652 deaths across 210 countries and territories by April 13, 2020 [4].

Prior to the current 2019-nCoV pandemic, there have been multiple episodes of global outbreak of acute respiratory disease caused by various strains of influenza virus. The most recent episode was the 2009 influenza A (H1N1) pandemic which spread over 214 countries between March 2009 and August 2010 resulting in 18,449 laboratory-confirmed fatalities globally [5]. While the influenza pandemic might be said to be over, the H1N1 as well as other strains of influenza virus have remained with us as seasonal viruses, resulting in the annual seasonal influenza epidemics [6]. Influenza occurs globally affecting $5-10 \%$ of adults and $20-30 \%$ of children annually with most cases occurring during the winter months in the northern (November to April) and southern hemispheres (April to September) with no seasonal pattern in the tropical regions [7, 8]. Influenza-related respiratory diseases are responsible annually for an estimated 650,000 deaths globally [9]. With the current global focus on the 2019-nCoV outbreak, the threat from the existence of the equally contagious influenza virus with seasonal manifestations cannot be downplayed.

SARS-CoV-2 and influenza primarily affect the respiratory system. SARS-CoV-2 gains access to the host cells using 
its surface spike (S) protein to bind human angiotensinconverting enzyme 2 receptor on host cells. The viral entry triggers a host immune response with a massive release of cytokines thought to be responsible for organ dysfunctions [10]. Influenza enters the epithelial cells and alveolar macrophages using two surface proteins, hemagglutinin which binds to sialic acid-containing molecules and neuraminidase which cleaves sialic acid to facilitate viral entry into host cells [11]. An inflammatory response follows with the recruitment of neutrophils, macrophages, and other immune cells. While this response is important for viral clearance, it also plays a role in various disease manifestations [12].

Most cases of 2019-nCoV infection are asymptomatic or present with mild symptoms. In a series of 72,314 2019$\mathrm{nCoV}$ cases published by the Chinese center for disease control, only $19 \%$ of cases had severe or critical disease with a case fatality rate of $2.3 \%$ [13]. The common symptoms manifested by affected individuals are fever, fatigue, cough, and sputum production. Sore throat, muscle pain, and gastrointestinal symptoms including nausea, vomiting, and diarrhea were less commonly reported [14-17]. This is similar to the clinical picture in influenza with fever, cough, and sore throat being often mentioned [18]. The reported findings from laboratory studies in individuals with 2019$\mathrm{nCoV}$ include leukopenia, lymphopenia, elevated C-reactive protein, elevated lactate dehydrogenase, elevated aspartate transaminase, and prolonged prothrombin time [14, 19]. This is similar to the laboratory reports for cases of influenza [20]. Although these findings are not diagnostic of 2019$\mathrm{nCoV}$ or influenza infection, they correlate with the risk of increased severity such as the development of acute respiratory distress syndrome and death $[21,22]$.

The gold standard for the diagnosis of these viral infections is the confirmation of viral RNA by real-time reverse transcriptase polymerase chain reaction (RT-PCR). However, based on a previous report on 2019-nCoV, the positive rate of RT-PCR at initial presentation is $30-60 \%$. This may be due to a low viral load, hence the need for repeated testing $[23,24]$. The available kits for testing influenza viruses reportedly have a sensitivity of $66-100 \%$ [25]. Although not a substitute for RT-PCR in the diagnosis of COVID-19 and influenza, chest computed tomography (CT) has been found to have an increasing use in the management of viral pneumonia [24].

Other imaging modality such as plain chest radiograph is useful in the evaluation of many chest disorders including viral chest infections. It however fails in the detection of early interstitial diseases. Ultrasonography has been employed in the detection of interstitial disorders, consolidation, and effusions [26]. CT scans, however, have a higher resolution and a greater ability to provide detailed anatomy, making it a superior tool in the evaluation of patients with 2019-nCoV and influenza. There is a need to clearly differentiate between these two conditions on imaging due to the similarities in clinical symptomatology as well as laboratory findings, in order to give focused care targeted at each condition. This study therefore focuses on a review of literature to assess the differentiating chest CT findings in 2019-nCoV infection and influenza.
TABLE 1: Demographic characteristics and number of CT scans done.

\begin{tabular}{|c|c|c|c|c|}
\hline Author & $\begin{array}{l}\text { Study } \\
\text { group }\end{array}$ & $\begin{array}{l}\text { Sample } \\
\text { size }\end{array}$ & $\begin{array}{c}\text { Mean } \\
\text { age/range } \\
\text { (years) }\end{array}$ & $\begin{array}{l}\text { Number of } \\
\text { CT scans }\end{array}$ \\
\hline $\mathrm{Xu}$ et al. [27] & $\mathrm{C}$ & 90 & $(37-78)$ & Multiple \\
\hline $\begin{array}{l}\text { Yang et al. } \\
{[28]}\end{array}$ & $\mathrm{C}$ & 149 & 45.0 & Multiple \\
\hline $\begin{array}{l}\text { Wang et al. } \\
\text { [29] }\end{array}$ & $\mathrm{C}$ & 90 & 45.0 & Multiple \\
\hline Lu et al. [16] & $\mathrm{C}$ & 11 & 50.0 & Single \\
\hline $\begin{array}{l}\text { Zhou et al. } \\
{[30]}\end{array}$ & $\mathrm{C}$ & 62 & $52.8(30-77)$ & Multiple \\
\hline Shi et al. [31] & $\mathrm{C}$ & 81 & 49.5 & Multiple \\
\hline $\begin{array}{l}\text { Zhao et al. } \\
{[32]}\end{array}$ & $\mathrm{C}$ & 101 & $44.4(17-75)$ & Single \\
\hline $\begin{array}{l}\text { Han et al. } \\
{[17]}\end{array}$ & $\mathrm{C}$ & 108 & $45.0(21-90)$ & Single \\
\hline $\begin{array}{l}\mathrm{Li} \text { and Xia } \\
\text { [33] }\end{array}$ & $\mathrm{C}$ & 51 & $58.0(26-83)$ & Single \\
\hline $\begin{array}{l}\text { Amorim } \\
\text { et al. [34] }\end{array}$ & I & 71 & $41.3(16-92)$ & Single \\
\hline $\begin{array}{l}\text { Elicker et al. } \\
\text { [35] }\end{array}$ & I & 20 & 48.2 & Multiple \\
\hline $\begin{array}{l}\text { Henzler et al. } \\
{[36]}\end{array}$ & I & 10 & 44.1 & Single \\
\hline $\begin{array}{l}\text { Jartti et al. } \\
\text { [37] }\end{array}$ & I & 135 & $46.8(25-74)$ & Single \\
\hline $\begin{array}{l}\text { Marchiori } \\
\text { et al. [38] }\end{array}$ & I & 20 & $42.7(24-72)$ & Single \\
\hline $\begin{array}{l}\text { Nicolini et al. } \\
\text { [39] }\end{array}$ & I & 28 & 53.8 & Single \\
\hline $\begin{array}{l}\text { Shim et al. } \\
{[40]}\end{array}$ & I & 21 & $37.0(6-82)$ & Single \\
\hline $\begin{array}{l}\text { Valente et al. } \\
{[41]}\end{array}$ & I & 42 & $40.9(21-76)$ & Multiple \\
\hline
\end{tabular}

C: COVID-19; I: influenza.

\section{Methodology}

This study is based on a review of published literature on the chest CT findings in COVID-19 and influenza. Literature search was done using PubMed to find MEDLINE indexed articles relevant to this study. The search was conducted using the keywords 'COVID-19', 'SARS-CoV-2', 'chest CT scan', 'influenza', 'pandemic', or any combination of these terms. The search terms yielded 435 studies. Using abstracts, two investigators independently selected articles for full-text review. Discrepancies were jointly reviewed and decided upon.

The inclusion criteria used were (1) original studies in the form of case series, cohort, and retrospective studies; (2) a sample size of at least 10; (3) studies conducted in adult patients ( $\geq 18$ years); (4) written in English; and (5) carried out since the onset of the 2009 global influenza pandemic till date. Exclusion criteria included (1) editorials and studies with unavailable raw data, (2) repeated published articles, and (3) case reports. The full texts of 17 selected studies were 
TABle 2: Parenchymal changes.

\begin{tabular}{|c|c|c|c|c|c|c|c|c|c|}
\hline Author & $\begin{array}{l}\text { Study } \\
\text { group }\end{array}$ & $\begin{array}{l}\text { GGO, } \\
N(\%)\end{array}$ & $\begin{array}{c}\text { Consolidation, } \\
N(\%)\end{array}$ & $\begin{array}{c}\text { GGO } \\
\text { +consolidation, } \\
N(\%)\end{array}$ & $\begin{array}{l}\text { Nodules, } \\
N(\%)\end{array}$ & $\begin{array}{c}\text { Crazy-paving } \\
\text { appearance, } N \\
(\%)\end{array}$ & $\begin{array}{c}\text { Linear } \\
\text { opacity, } N \\
(\%)\end{array}$ & $\begin{array}{l}\text { Interlobular septal } \\
\text { thickening, } N(\%)\end{array}$ & $\begin{array}{c}\text { Reticular } \\
\text { pattern, } N \\
(\%)\end{array}$ \\
\hline $\begin{array}{l}\text { Xu et al. } \\
{[27]}\end{array}$ & $\mathrm{C}$ & $\begin{array}{c}65 \\
(72.0)\end{array}$ & $12(13.0)$ & - & - & $11(12.0)$ & $55(61.0)$ & $33(37.0)$ & $48(53.0)$ \\
\hline $\begin{array}{l}\text { Yang et al. } \\
{[28]}\end{array}$ & $\mathrm{C}$ & $\begin{array}{c}18 \\
(12.1)\end{array}$ & $11(7.2)$ & $40(26.8)$ & $3(2.0)$ & - & - & - & $79(53.0)$ \\
\hline $\begin{array}{l}\text { Wang } \\
\text { et al. [29] }\end{array}$ & $\mathrm{C}$ & $\begin{array}{c}41 \\
(45)-55 \\
(62)\end{array}$ & - & - & - & $22(24.0)$ & - & - & - \\
\hline $\begin{array}{l}\text { Lu et al. } \\
{[16]}\end{array}$ & $\mathrm{C}$ & $\begin{array}{c}11 \\
(100.0)\end{array}$ & $6(54.5)$ & $7(63.6)$ & $3(27.3)$ & - & $2(18.2)$ & - & $73(81.8)$ \\
\hline $\begin{array}{l}\text { Zhou et al. } \\
\text { [30] }\end{array}$ & $\mathrm{C}$ & $\begin{array}{c}25 \\
(40.3)\end{array}$ & $21(33.9)$ & - & - & - & - & - & - \\
\hline $\begin{array}{l}\text { Shi et al. } \\
\text { [31] }\end{array}$ & $\mathrm{C}$ & $\begin{array}{c}53 \\
(65.0)\end{array}$ & $24(30)$ & - & $4(6.0)$ & $8(10.0)$ & - & $28(35.0)$ & - \\
\hline $\begin{array}{l}\text { Zhao et al. } \\
\text { [32] }\end{array}$ & $\mathrm{C}$ & $\begin{array}{c}87 \\
(86.1)\end{array}$ & $44(43.6)$ & $65(64.4)$ & - & - & - & - & 49 (48.5) \\
\hline $\begin{array}{l}\text { Han et al. } \\
\text { [17] }\end{array}$ & $\mathrm{C}$ & $\begin{array}{c}65 \\
(60.0)\end{array}$ & - & $44(41.0)$ & - & $43(40.0)$ & - & - & - \\
\hline $\begin{array}{l}\mathrm{Li} \text { and Xia } \\
\text { [33] }\end{array}$ & $\mathrm{C}$ & $\begin{array}{c}28 \\
(54.9)\end{array}$ & - & $28(54.9)$ & $11(21.5)$ & $36(70.6)$ & - & $36(70.6)$ & - \\
\hline $\begin{array}{l}\text { Amorim } \\
\text { et al. [34] }\end{array}$ & I & $\begin{array}{c}60 \\
(85.0)\end{array}$ & $45(64.0)$ & $41(58.0)$ & $18(25.0)$ & $11(15.0)$ & - & $15(21.0)$ & - \\
\hline $\begin{array}{l}\text { Elicker } \\
\text { et al. [35] }\end{array}$ & I & $\begin{array}{c}13 \\
(65.0)\end{array}$ & $17(85.0)$ & - & $8(40.0)$ & - & - & - & - \\
\hline $\begin{array}{l}\text { Henzler } \\
\text { et al. [36] }\end{array}$ & I & $9(90)$ & $8(80)$ & - & - & $4(40.0)$ & - & - & $2(20.0)$ \\
\hline $\begin{array}{l}\text { Jartti et al. } \\
\text { [37] }\end{array}$ & I & $\begin{array}{c}100 \\
(74.0)\end{array}$ & $126(93.0)$ & - & $24(18.0)$ & - & - & - & - \\
\hline $\begin{array}{l}\text { Marchiori } \\
\text { et al. [38] }\end{array}$ & I & $\begin{array}{c}12 \\
(60.0)\end{array}$ & $2(10.0)$ & $6(30.0)$ & 0 & - & - & - & - \\
\hline $\begin{array}{l}\text { Nicolini } \\
\text { et al. [39] }\end{array}$ & I & $\begin{array}{c}24 \\
(84.5)\end{array}$ & - & - & - & $7(25.0)$ & - & - & - \\
\hline $\begin{array}{l}\text { Shim et al. } \\
{[40]}\end{array}$ & I & $\begin{array}{c}20 \\
(95.0)\end{array}$ & $6(29.0)$ & - & $3(14.0)$ & - & - & $1(5.0)$ & - \\
\hline $\begin{array}{l}\text { Valente } \\
\text { et al. [41] }\end{array}$ & I & $\begin{array}{c}14 \\
(33.3)\end{array}$ & $6(14.3)$ & $22(52.4)$ & $2(4.8)$ & - & - & $3(7.10)$ & 5 (11.9) \\
\hline
\end{tabular}

$N$ : number of cases: C: COVID-19; I: influenza; GGO: ground-glass opacity.

reviewed. Nine were COVID-19 studies and eight were articles on influenza. This resulted in reviewing $347 \mathrm{CT}$ findings for COVID-19 and 743 for influenza.

Demographic information such as sample size, mean age, and range was tabulated. Frequency tables of the chest CT findings were established using the following categories: parenchymal features, distribution of parenchyma features, bronchovascular changes, pleural involvement, and extrapleural findings. Features not found were represented as “ 0 ," while unreported features were indicated by “-.”

\section{Results}

A total of 17 studies, made up of 9 studies on COVID-19 and 8 on influenza, formed the basis of the comparison. The number of cases ranges from 11 to 149 and 10 to 135 in
COVID-19 and influenza, respectively. The mean age in both set of studies is similar with most lying between 40 and 50 years (Table 1). The most common parenchyma lesions reported in both studies are ground-glass opacities (GGO) found in $12.1-100 \%$ in all COVID-19 studies and $33.3 \%$ $95 \%$ in all influenza studies, followed by consolidation, reported in 7.2-54.5\% in 6 COVID-19 studies and 14.3-93\% in 6 influenza studies (Table 2). A mixed pattern of GGO with consolidation was found in $26.8-64.4 \%$ in 5 COVID19 studies and $30-58 \%$ in 3 influenza studies. Nodules were reported in $2-27.3 \%$ in 4 COVID-19 studies and $4.8-66 \%$ in 4 influenza studies. A crazy-paving pattern reported was $12-70.6 \%$ in 5 COVID-19 studies and $15-40 \%$ in 3 influenza studies. A reticular pattern was found as $48.5-81.8 \%$ in 4 COVID-19 studies and in 11.9-20\% in 2 influenza studies (Table 2). Other parenchyma findings are interlobular septal 
TABle 3: Predominant location of parenchymal findings.

\begin{tabular}{|c|c|c|c|c|c|c|}
\hline Author & $\begin{array}{l}\text { Study } \\
\text { group }\end{array}$ & $\begin{array}{c}\text { Multifocal distribution, } \\
\qquad N(\%)\end{array}$ & $\begin{array}{c}\text { No. of lobes, } N \\
(\%)\end{array}$ & $\begin{array}{c}\text { Bilateral distribution, } \\
\qquad N(\%)\end{array}$ & $\begin{array}{c}\text { Peripheral or central, } \\
\qquad N(\%)\end{array}$ & Upper/middle/lower \\
\hline $\mathrm{Xu}$ et al. [27] & $\mathrm{C}$ & MF $62(69.0)$ & $\begin{array}{c}>1 \text { lobe } 53 \\
\quad(59.0)\end{array}$ & B $53(59.0)$ & P 46 (51.0) & $\mathrm{L}$ \\
\hline Yang et al. [28] & $\mathrm{C}$ & - & - & - & P 53 (35.9) & $\mathrm{L}$ \\
\hline Wang et al. [29] & $\mathrm{C}$ & - & $>1$ lobe & B & $\mathrm{P}$ & - \\
\hline Lu et al. [16] & $\mathrm{C}$ & MF 9 (83.9) & $>1$ lobe & - & P $11(100.0)$ & $\mathrm{L}$ \\
\hline Zhou et al. [30] & $\mathrm{C}$ & - & - & - & P 48 (77.4) & - \\
\hline Shi et al. [31] & $\mathrm{C}$ & MF $43(53.0)$ & - & В $64(79.0)$ & P $44(54.0)$ & $\mathrm{L}$ \\
\hline Zhao et al. [32] & $\mathrm{C}$ & MF 55 (54.5) & $\begin{array}{c}>1 \text { lobe } 66 \\
\quad(65.0)\end{array}$ & B $83(82.2)$ & P 88 (87.1) & $\mathrm{L}$ \\
\hline Han et al. [17] & $\mathrm{C}$ & - & - & - & P $97(90.0)$ & - \\
\hline $\mathrm{Li}$ and Xia [33] & $\mathrm{C}$ & - & $\begin{array}{l}5 \text { lobes } 38 \\
\quad(75.0)\end{array}$ & - & P 49 (96.1) & - \\
\hline $\begin{array}{l}\text { Amorim et al. } \\
{[34]}\end{array}$ & I & - & - & B $63(89.0)$ & - & $\mathrm{R}$ \\
\hline $\begin{array}{l}\text { Elicker et al. } \\
\text { [35] }\end{array}$ & I & - & - & B $20(100.0)$ & - & - \\
\hline $\begin{array}{l}\text { Henzler et al. } \\
{[36]}\end{array}$ & I & - & - & - & $\mathrm{R}$ & $\mathrm{R}$ \\
\hline Jartti et al. [37] & I & - & $\begin{array}{l}5 \text { lobes } 101 \\
\quad(75.0)\end{array}$ & - & P 74 (55) & $\mathrm{L}$ \\
\hline $\begin{array}{l}\text { Marchiori et al. } \\
\text { [38] }\end{array}$ & I & - & - & B $20(100.0)$ & P $13(65.0)$ & - \\
\hline $\begin{array}{l}\text { Nicolini et al. } \\
\text { [39] }\end{array}$ & I & $\mathrm{MF}>14(>50.0)$ & - & B & - & $\mathrm{L}$ \\
\hline Shim et al. [40] & I & $\mathrm{MF}>11(>50.0)$ & - & - & Ce $12(60.0)$ & $\mathrm{L}$ \\
\hline $\begin{array}{l}\text { Valente et al. } \\
\text { [41] }\end{array}$ & I & - & - & - & Ce $18(44.3)$ & - \\
\hline
\end{tabular}

$N$ : number of cases; C: COVID-19; I: influenza; MF: multifocal; B: bilateral; R: random, Ce: central; P: periphery; L: lower.

thickening, reported in 35-70.6\% in 3 COVID-19 studies and $5-21 \%$ in 3 influenza studies, and linear opacity, found in $18.2-61 \%$ in 2 COVID-19 studies.

The predominant distribution of lesions is multifocal, reported in $53-83.9 \%$ in 4 COVID-19 studies and $>50 \%$ in 2 influenza studies, multilobar, with 5 COVID-19 studies reporting more than 1 lobar involvement in $59-75 \%$ of cases and 1 study on influenza reporting multilobar predominance in $75 \%$ of cases. Most are bilaterally distributed, found in 59$82.2 \%$ in 3 COVID-19 studies and $71-100 \%$ in 5 influenza studies. All COVID-19 studies found a peripheral predominance of distribution in 35.9-100\% of cases, while 2 influenza studies reported a peripheral distribution in 55-65\% of cases and 2 studies reported central distribution in $44.3-60 \%$ of cases. The lower lobe was the predominantly affected lobe in 5 COVID-19 and 3 influenza studies (Table 3).

Bronchovascular changes reported in the studies include air bronchogram reported as $8-72.7 \%$ of 7 COVID-19 studies and none in influenza studies. Peribronchovascular predominance of lesions was reported as $10-75 \%$ in 5 COVID-19 studies only. Bronchial dilatation was found in $11-52.5 \%$ in 3 COVID-19 and $45 \%$ in one study on influenza. Vascular engorgement was reported as $71.3-82.4 \%$ in 4 COVID-19 studies only. Tree-in-bud appearance was found only in one study on COVID-19, 9.1\%; none was reported in the influenza studies (Table 4).

\section{Discussion}

Clinical differentiation of COVID-19 from influenza is challenging because both diseases have an asymptomatic period of just over a week. During this asymptomatic period, the infection can be transmitted [22]. In a recent study, radiologists could differentiate COVID-19 from other viral pneumonia about $74 \%$ of the time on chest CT images [24]. In this review, chest CT features of COVID-19 were compared to those of influenza [24]. Differences were observed in each of the following categories: parenchymal features and their distribution, bronchovascular changes, and pleural and extrapleural findings.

GGO are hazy areas of increased lung density that do not obscure bronchial and vascular markings [42]. It can be due to partial filling of airspaces or interstitial thickening [34]. Previous studies have identified GGO as the earliest and predominant CT abnormality in COVID-19 patients [16]. A recent study found that GGO was predominantly unilateral, multifocal, and peripheral in preclinical patients but became bilateral and more diffuse in the first week after the onset of 
TABLE 4: Bronchovascular findings.

\begin{tabular}{|c|c|c|c|c|c|c|}
\hline Author & $\begin{array}{l}\text { Study } \\
\text { group }\end{array}$ & $\begin{array}{c}\text { Peribronchovascular, } \\
N(\%)\end{array}$ & $\begin{array}{c}\text { Air bronchogram, } \\
N(\%)\end{array}$ & $\begin{array}{c}\text { Bronchial dilatation, } \\
N(\%)\end{array}$ & $\begin{array}{c}\text { Vascular engorgement, } \\
N(\%)\end{array}$ & $\begin{array}{c}\text { Tree-in-bud, } N \\
(\%)\end{array}$ \\
\hline Xu et al. [27] & C & - & $7(8.0)$ & - & - & - \\
\hline Yang et al. [28] & C & - & $81(54.4)$ & - & - & - \\
\hline Wang et al. [29] & $\mathrm{C}$ & - & - & - & - & - \\
\hline Lu et al. [16] & $\mathrm{C}$ & - & $8(72.7)$ & $3(27.3)$ & - & $1(9.1)$ \\
\hline Zhou et al. [30] & $\mathrm{C}$ & - & $45(72.6)$ & - & $35(56.5)$ & - \\
\hline Shi et al. [31] & $\mathrm{C}$ & - & $38(47.0)$ & $9(11.0)$ & - & 0 \\
\hline Zhao et al. [32] & $\mathrm{C}$ & - & - & $53(52.5)$ & $72(71.3)$ & - \\
\hline Han et al. [17] & $\mathrm{C}$ & - & $52(48.0)$ & - & $86(80.0)$ & - \\
\hline $\mathrm{Li}$ and $\mathrm{Xia}$ [33] & $\mathrm{C}$ & - & $35(68.6)$ & - & $42(82.4)$ & - \\
\hline $\begin{array}{l}\text { Amorim et al. } \\
{[34]}\end{array}$ & I & $8(11.0)$ & - & - & - & - \\
\hline $\begin{array}{l}\text { Elicker et al. } \\
\text { [35] }\end{array}$ & I & $3(12.5)$ & - & $9(45.0)$ & - & - \\
\hline $\begin{array}{l}\text { Henzler et al. } \\
{[36]}\end{array}$ & I & - & - & - & - & - \\
\hline Jartti et al. [37] & I & $96(71.0)$ & - & - & - & - \\
\hline $\begin{array}{l}\text { Marchiori et al. } \\
\text { [38] }\end{array}$ & I & - & - & - & - & - \\
\hline $\begin{array}{l}\text { Nicolini et al. } \\
{[39]}\end{array}$ & I & $2.8(10.0)$ & - & - & & \\
\hline Shim et al. [40] & I & $16(75.0)$ & - & - & - & - \\
\hline $\begin{array}{l}\text { Valente et al. } \\
\text { [41] }\end{array}$ & I & - & - & - & - & - \\
\hline
\end{tabular}

$N$ : number of cases; C: COVID-19; I: influenza.

symptoms [31]. In another study, GGO increased in opacity within 1-3 weeks to become consolidated [16]. The common findings on CT for typical influenza pneumonia consist of diffuse or multifocal ground-glass opacities and small centrilobular nodules [15]. In this study, the occurrence of groundglass opacification and consolidation in COVID-19 were not markedly different from that of influenza studies. However, they were predominantly located bilaterally within the lower lobes for COVID-19 patients, while in the influenza studies, they were more widespread, involving all the lobes. This is similar to a recent study in which the GGO of COVID-19 patients were found predominantly peripheral (i.e., outer one-third). The occurrence of GGO and consolidation in this study contrasted with a recent comparative study which reported COVID-19 patients had significantly higher probability of ground-glass opacity appearance relative to other viral pneumonias (91 vs. 68\%, $p<0.001$ ) [24]. This is likely due to differences in time-to-imaging.

Consolidation is opacification that occurs by pathological tissues, cells, or fluid replacing the alveolar cells, obscuring the underlying vessels $[42,43]$. It can be segmental or subsegmental [44]. Consolidation has been reported as the second predominant feature in COVID-19 patients within the first few days of disease onset, the presence of which could indicate an increase in disease severity [42].

The crazy-paving pattern manifests with thickened interlobular septal and intralobular lines superimposed on ground-glass opacity $[6,42,45]$. Crazy pattern and reticular changes were more reported in COVID-19 studies. A previous study reported a higher likelihood of reticular changes in COVID-19 patients [24]. It was noted that fine reticular opacities in COVID-19 patients appear with a ratio of 56 vs. $22 \%$ ( $p$ value $<0.001)$ which is a result of the thickening of the pulmonary interstitial structures such as interlobular lines and interlobular septa $[17,30,33]$. The presence of the crazy-paving pattern could indicate an advanced disease stage, as it was the main finding in the third week after the onset of symptoms in a recent study [31].

A nodule is a round or irregular opacity of less than $3 \mathrm{~cm}$ in diameter with sharp or ill-defined margins. They are classified as centrilobular or "tree-in-bud" nodules and discrete focal nodules [6]. Nodules, particularly centrilobular nodules, are less commonly seen with pneumonia-like infections such as COVID-19 and influenza [46]. This is similar to findings in this review. Bacterial superinfection may be suggested when patients have pleural effusion, extensive tiny lung nodules, and lymphadenopathy [42].

Pleural changes can either be reported as pleural effusion or pleural thickening. Pleura effusion is the filling of the pleural space with fluid [47]. It could be transudative-normal pleural or exudative-fluid from infection [47]. In this review, pleural effusion was rarely found with COVID-19 (Table 5). This is similar to findings in other studies [30, 48]. It occurs less frequently than pleural thickening. The presence of pleural 
TABLe 5: Pleural and extrapleural findings.

\begin{tabular}{|c|c|c|c|c|c|c|c|c|}
\hline Author & $\begin{array}{l}\text { Study } \\
\text { group }\end{array}$ & $\begin{array}{c}\text { Pleural } \\
\text { effusion, } N \\
(\%)\end{array}$ & $\begin{array}{c}\text { Pleural } \\
\text { thickening, } \\
N(\%)\end{array}$ & $\begin{array}{l}\text { Lymphadenopathy, } \\
N(\%)\end{array}$ & $\begin{array}{l}\text { Pericardial } \\
\text { effusion, } N \\
(\%)\end{array}$ & $\begin{array}{l}\text { Pneumomediastinum, } \\
\qquad N(\%)\end{array}$ & $\begin{array}{c}\text { Pneumothorax, } \\
N(\%)\end{array}$ & $\begin{array}{r}\text { Subpleural } \\
\text { line, } N(\%)\end{array}$ \\
\hline $\begin{array}{l}\text { Xu et al. } \\
{[27]}\end{array}$ & C & $4(4.0)$ & $50(56.0)$ & $1(1.0)$ & $1(1.0)$ & - & - & - \\
\hline $\begin{array}{l}\text { Yang et al. } \\
{[28]}\end{array}$ & $\mathrm{C}$ & $10(6.7)$ & - & $7(4.7)$ & - & - & - & - \\
\hline $\begin{array}{l}\text { Wang } \\
\text { et al. [29] }\end{array}$ & C & $6(7.0)$ & - & 0 & - & 0 & 0 & - \\
\hline $\begin{array}{l}\text { Lu et al. } \\
{[16]}\end{array}$ & $\mathrm{C}$ & - & - & 0 & 0 & - & - & - \\
\hline $\begin{array}{l}\text { Zhou et al. } \\
\text { [30] }\end{array}$ & C & $6(9.7)$ & $30(48.4)$ & - & - & - & - & $21(33.9)$ \\
\hline $\begin{array}{l}\text { Shi et al. } \\
\text { [31] }\end{array}$ & $\mathrm{C}$ & $4(5.0)$ & $26(32.0)$ & $4(6.0)$ & - & - & - & - \\
\hline $\begin{array}{l}\text { Zhao et al. } \\
\text { [32] }\end{array}$ & $\mathrm{C}$ & 14 (13.9) & - & $1(1)$ & - & - & - & $28(27.7)$ \\
\hline $\begin{array}{l}\text { Han et al. } \\
\text { [17] }\end{array}$ & $\mathrm{C}$ & 0 & 0 & 0 & - & - & - & - \\
\hline $\begin{array}{l}\text { Li and Xia } \\
\text { [33] }\end{array}$ & C & $1(1.0)$ & - & 0 & - & - & - & - \\
\hline $\begin{array}{l}\text { Amorim } \\
\text { et al. [34] }\end{array}$ & I & $19(27.0)$ & - & 0 & - & - & - & - \\
\hline $\begin{array}{l}\text { Elicker } \\
\text { et al. [35] }\end{array}$ & I & $7(35.0)$ & - & $1(5.0)$ & $3(15.0)$ & - & - & - \\
\hline $\begin{array}{l}\text { Henzler } \\
\text { et al. [36] }\end{array}$ & I & $9(90.0)$ & - & $1(10.0)$ & - & - & - & - \\
\hline $\begin{array}{l}\text { Jartti et al. } \\
\text { [37] }\end{array}$ & I & $8(6.0)$ & - & - & 17 (12.5) & - & - & - \\
\hline $\begin{array}{l}\text { Marchiori } \\
\text { et al. [38] }\end{array}$ & I & $5(25.0)$ & - & 0 & - & - & - & - \\
\hline $\begin{array}{l}\text { Nicolini } \\
\text { et al. [39] }\end{array}$ & I & $6(21.0)$ & - & 0 & - & - & - & - \\
\hline $\begin{array}{l}\text { Shim et al. } \\
\text { [40] }\end{array}$ & I & $6(29.0)$ & - & - & - & $5(24.0)$ & - & - \\
\hline $\begin{array}{l}\text { Valente } \\
\text { et al. [41] }\end{array}$ & I & $7(16.7)$ & - & $6(14.3)$ & - & $1(2.4)$ & $2(5.0)$ & - \\
\hline
\end{tabular}

$N$ : number of cases; C: COVID-19; I: influenza.

effusion may suggest a poor prognosis in COVID-19 patients [17]. Pleural thickening is a process where the pleura is thickened, usually with scar tissue [47], and it could be caused by acute inflammation of the pleura. The subpleural line is a thin curvilinear opacity of about $1-3 \mathrm{~mm}$ in thickness found close to the pleural surface [12]. It is located in the subpleural region and distributed parallel to the pleural surface. Pleural thickening was observed only in COVID-19 cases. Similarly, subpleural thickening was also reported only in COVID-19 studies (Table 5). The peripheral location of ground-glass opacities in COVID-19 patients may be a contributory factor for the relative increase of pleural and subpleural thickening identified on images.

Pneumothorax is air within the pleural space, while pneumomediastinum is air within the mediastinum. They are rarely seen in COVID-19 and influenza. The most common cause of pneumomediastinum is rupture of the alveoli, due to coughing, vomiting, straining, or blunt chest trauma [49]. Free air may dissect through the visceral pleura causing pneumothorax or track centrally to the hilum and mediastinum causing pneumomediastinum [38]. Pneumothorax and pneumomediastinum were only reported in influenza studies reviewed. In a recent study, all the patients with pneumomediastinum needed extracorporeal membrane oxygenation and advanced mechanical ventilation [41]. The threshold for mediastinal lymphadenopathy is a short axis diameter of $1 \mathrm{~cm}$ [50]. The occurrence of lymphadenopathy in the studies reviewed was low and relatively lower in COVID-19 studies. This is similar to findings by a recent study which observed lymphadenopathy in $2.7 \%$ of COVID-19 patients and $10.0 \%$ of nonCOVID-19 patients $(p<0.001)$ [24]. However, the presence of lymphadenopathy is considered a significant risk factor for severe COVID-19 pneumonia; this may be due to bacterial superinfection [31]. 


\section{Conclusion}

This review compared chest CT findings of COVID-19 and H1N1 influenza cases using existing publications. The differences found show that COVID-19 ground-glass opacities are usually peripherally located compared with influenza which also had central and random locations. Vascular engorgement, pleural thickening, and subpleural lines were more frequently reported in COVID-19 patients. Lymphadenopathy was rare in both COVID-19 and influenza patients. In contrast, pneumomediastinum and pneumothorax were reported only in studies on influenza.

5.1. Limitations. There are limitations to this review. Firstly, COVID-19 is relatively novel and thus the studies are limited in number. The CT findings reported about influenza were before the onset of COVID 19. A direct comparison of pictures now may better define the differences. Secondly, the review could not accurately account for the differences in time to imaging relative to the onset of symptoms. Thirdly, this review cannot account for findings due to the use of various machine models and imaging protocols. Finally, the use of abstracts in selecting full texts for a detailed review could have led to the omission of some articles. A meta-analysis is recommended to further define the differences and the degree between COVID-19 and influenza.

\section{Conflicts of Interest}

The authors declare that there is no conflict of interest regarding the publication of this paper.

\section{References}

[1] Wuhan Municipal Health Commission, "Report of novel coronavirus-infected pneumonia in China," vol. 20, 2020April 2020, http://wjw.wuhan.gov.cn/front/web/showDetail/ 2020012009077.

[2] European Centre for Disease Prevention and Control, Rapid Risk Assessment: outbreak of acute respiratory syndrome associated with a novel coronavirus, Wuhan, China; second update-26 January 2020, ECDC, Stockholm, 2020, April 2020, https://www.ecdc.europa.eu/sites/default/files/ documents/Risk-assessment-pneumonia-Wuhan-China-26Jan-2020_0.pdf.

[3] World Health Organization, "Novel coronavirus (2019nCoV): situation report-9," April 2020, https://www.who.int/ docs/default-source/coronaviruse/situation-reports/ 20200413-sitrep-84-covid-19.pdf?sfvrsn=44f511ab_2.

[4] World Health Organization, "Novel coronavirus (2019nCoV): situation report-74," April 2020. https://www.who .int/docs/default-source/coronaviruse/situation-reports/ 20200403-sitrep-74-covid-19-mp.pdf?sfvrsn=4e043d03_12.

[5] World Health Organization, "Emergency preparedness, response: pandemic (H1N1) 2009 update 112," April 2020. https://www.who.int/csr/don/2010_08_06/en/.

[6] S. L. Aquino, D. P. Dunagan, C. Chiles, and E. F. Haponik, "Herpes simplex virus 1 pneumonia: patterns on CT scans and conventional chest radiographs," Journal of Computer Assisted Tomography, vol. 22, no. 5, pp. 795-800, 1998, 10.1097/00004728-199809000-00024.
[7] C. A. Russell, T. C. Jones, I. G. Barr et al., "Influenza vaccine strain selection and recent studies on the global migration of seasonal influenza viruses," Vaccine, vol. 26, no. 4, pp. D31D34, 2008.

[8] World Health Organization, "International travel and health: seasonal influenza and influenza A (H1N1)," April 2020, https://www.who.int/ith/diseases/si_iAh1n1/en/.

[9] World Health Organization, "Up to 650,000 people die of respiratory diseases linked to seasonal flu each year," April 2020, http://www.who.int/mediacentre/news/releases/2017/ seasonal-flu/en/.

[10] L. Du, Y. He, Y. Zhou, S. Liu, B.-J. Zheng, and S. Jiang, “The spike protein of SARS-CoV - a target for vaccine and therapeutic development," Nature Reviews. Microbiology, vol. 7, no. 3, pp. 226-236, 2009.

[11] A. García-Sastre, "Influenza virus receptor specificity: disease and transmission," American Journal of Pathology, vol. 176, no. 4, pp. 1584-1585, 2010.

[12] G. Laghlali, K. E. Lawlor, and M. D. Tate, "Die another way: interplay between influenza A virus, inflammation and cell death," Viruses, vol. 12, no. 4, p. 401, 2020.

[13] Z. Wu and J. M. McGoogan, "Characteristics of and important lessons from the coronavirus disease 2019 (COVID-19) outbreak in China," Journal of American Medical Association, vol. 323, no. 13, pp. 1239-1242, 2020.

[14] D. Wang, B. Hu, C. Hu et al., "Clinical characteristics of 138 hospitalized patients with 2019 novel coronavirus-infected pneumonia in Wuhan, China," Journal of American Medical Association, vol. 323, no. 11, pp. 1061-1069, 2020.

[15] C.-C. Lai, Y. H. Liu, C.-Y. Wang et al., "Asymptomatic carrier state, acute respiratory disease, and pneumonia due to severe acute respiratory syndrome coronavirus 2 (SARS-CoV-2): facts and myths," Journal of Microbiology, Immunology and Infection, 2020.

[16] R. Lu, X. Zhao, J. Li et al., "Genomic characterisation and epidemiology of 2019 novel coronavirus: implications for virus origins and receptor binding," The Lancet, vol. 395, no. 10224, pp. 565-574, 2020.

[17] R. Han, L. Huang, H. Jiang, J. Dong, H. Peng, and D. Zhang, "Early clinical and CT manifestations of coronavirus disease 2019 (COVID-19) pneumonia," American Journal of Roentgenology, pp. 1-6, 2020.

[18] Novel Swine-Origin Influenza A (H1N1) Virus Investigation Team, "Emergence of a novel swine-origin influenza A (H1N1) virus in humans," New England Journal of Medicine, vol. 360, no. 25, pp. 2605-2615, 2009.

[19] T. Ai, Z. Yang, H. Hou et al., "Correlation of chest CT and RTPCR testing in coronavirus disease 2019 (COVID-19) in China: a report of 1014 cases," Radiological Society of North America, p. 200642, 2020.

[20] R. Perez-Padilla, D. de la Rosa-Zamboni, S. P. de Leon et al., "Pneumonia and respiratory failure from swine-origin influenza A (H1N1) in Mexico," New England Journal of Medicine, vol. 361, no. 7, pp. 680-689, 2009.

[21] X. Yang, Y. Yu, J. Xu et al., "Clinical course and outcomes of critically ill patients with SARS-CoV-2 pneumonia in Wuhan, China: a single-centered, retrospective, observational study," The Lancet Respiratory Medicine, vol. 8, no. 5, pp. 475-481, 2020.

[22] D. Zhao, F. Yao, L. Wang et al., "A comparative study on the clinical features of coronavirus 2019 (COVID-19) pneumonia with other pneumonias," Clinical Infectious Disease, 2020. 
[23] Y. Yang, M. Yang, C. Shen et al., Evaluating the accuracy of different respiratory specimens in the laboratory diagnosis and monitoring the viral shedding of 2019-nCoV infections, MedRxiv, 2020.

[24] H. X. Bai, B. Hsieh, Z. Xiong et al., "Performance of radiologists in differentiating COVID-19 from viral pneumonia on chest CT," Radiology, p. 200823, 2020.

[25] Centers for Disease Control and Prevention, "Influenza (flu): information on rapid molecular assays, RT-PCR, and other molecular assays for diagnosis of influenza virus infection," April 2020, https://www.cdc.gov/flu/professionals/diagnosis/ molecular-assays.htm.

[26] A. Testa, G. Soldati, R. Copetti, R. Giannuzzi, G. Portale, and N. Gentiloni-Silveri, "Early recognition of the 2009 pandemic influenza A (H1N1) pneumonia by chest ultrasound," Critical Care, vol. 16, no. 1, p. R30, 2012.

[27] X. Xu, C. Yu, J. Qu et al., "Imaging and clinical features of patients with 2019 novel coronavirus SARS-CoV-2," European Journal of Nuclear Medicine and Molecular Imaging, vol. 47, no. 5, pp. 1275-1280, 2020.

[28] W. Yang, Q. Cao, X. W. Le Qin et al., "Clinical characteristics and imaging manifestations of the 2019 novel coronavirus disease (COVID-19): a multi-center study in Wenzhou city, Zhejiang, China," Journal of Infection, vol. 80, no. 4, pp. 388-393, 2020.

[29] Y. Wang, C. Dong, Y. Hu et al., "Temporal changes of CT findings in 90 patients with COVID-19 pneumonia: a longitudinal study," Radiology, p. 200843, 2020.

[30] S. Zhou, Y. Wang, T. Zhu, and L. Xia, "CT features of coronavirus disease 2019 (COVID-19) pneumonia in 62 patients in Wuhan, China," American Journal of Roentgenology, vol. 214, no. 6, pp. 1-8, 2020.

[31] H. Shi, X. Han, N. Jiang et al., "Radiological findings from 81 patients with COVID-19 pneumonia in Wuhan, China: a descriptive study," The Lancet Infectious Diseases, vol. 20, no. 4, pp. 425-434, 2020.

[32] W. Zhao, Z. Zhong, X. Xie, Q. Yu, and J. Liu, "Relation between chest CT findings and clinical conditions of coronavirus disease (COVID-19) pneumonia: a multicenter study," American Journal of Radiology, vol. 214, no. 5, pp. 10721077, 2020.

[33] Y. Li and L. Xia, "Coronavirus disease 2019 (COVID-19): role of chest CT in diagnosis and management," American Journal of Roentgenology, pp. 1-7, 2020.

[34] V. B. Amorim, R. S. Rodrigues, M. M. Barreto, G. Zanetti, B. Hochhegger, and E. Marchiori, "Influenza A (H1N1) pneumonia: HRCT findings," Brazilian Journal of Pulmonology, vol. 39, no. 3, pp. 323-329, 2013.

[35] B. M. Elicker, B. S. Schwartz, C. Liu et al., "Thoracic CT findings of novel influenza A (H1N1) infection in immunocompromised patients," Emergency Radiology, vol. 17, no. 4, pp. 299-307, 2010.

[36] T. Henzler, M. Meyer, A. Kalenka et al., "Image findings of patients with $\mathrm{H} 1 \mathrm{~N} 1$ virus pneumonia and acute respiratory failure," Academic Radiology, vol. 17, no. 6, pp. 681-685, 2010.

[37] A. Jartti, E. Rauvala, H. Kauma, M. Renko, M. Kunnari, and H. Syrjälä, "Chest imaging findings in hospitalized patients with H1N1 influenza," Acta Radiologica, vol. 52, no. 3, pp. 297-304, 2011.

[38] E. Marchiori, G. Zanetti, B. Hochhegger et al., "High-resolution computed tomography findings from adult patients with influenza A (H1N1) virus-associated pneumonia," European Journal of Radiology, vol. 74, no. 1, pp. 93-98, 2010.

[39] A. Nicolini, L. Ferrera, F. Rao, R. Senarega, and M. FerrariBravo, "Chest radiological findings of influenza A H1N1 pneumonia," Revista Portuguesa de Pneumologia, vol. 18, no. 3, pp. 120-127, 2012.

[40] S. S. Shim, Y. Kim, and Y. J. Ryu, "Novel influenza A (H1N1) infection: chest CT findings from 21 cases in Seoul, Korea," Clinical Radiology, vol. 66, no. 2, pp. 118-124, 2011.

[41] T. Valente, F. Lassandro, M. Marino, F. Squillante, M. Aliperta, and R. Muto, "H1N1 pneumonia: our experience in 50 patients with a severe clinical course of novel swine-origin influenza A (H1N1) virus (S-OIV)," La Radiologia Medica, vol. 117, no. 2, pp. 165-184, 2012.

[42] Z. Ye, Y. Zhang, Y. Wang, Z. Huang, and B. Song, "Chest CT manifestations of new coronavirus disease 2019 (COVID19): a pictorial review," European Radiology, 2020.

[43] P. P. Agarwal, S. Cinti, and E. A. Kazerooni, "Chest radiographic and CT findings in novel swine-origin influenza A (H1N1) virus (S-OIV) infection," American Journal of Roentgenology, vol. 193, no. 6, pp. 1488-1493, 2009.

[44] F. Pan, T. Ye, P. Sun et al., "Time course of lung changes at chest CT during recovery from Coronavirus Disease 2019 (COVID-19)," Radiology, vol. 295, no. 3, pp. 715-721, 2020.

[45] S. E. Rossi, J. J. Erasmus, M. Volpacchio, T. Franquet, T. Castiglioni, and H. P. McAdams, “Crazy-paving' pattern at thin-section CT of the lungs: radiologic-pathologic overview," Radiographics, vol. 23, no. 6, pp. 1509-1519, 2003.

[46] J. F.-W. Chan, S. Yuan, K.-H. Kok et al., "A familial cluster of pneumonia associated with the 2019 novel coronavirus indicating person-to-person transmission: a study of a family cluster," The Lancet, vol. 395, no. 10223, pp. 514-523, 2020.

[47] "What is a pleural effusion?," https://www.webmd.com/lung/ pleural-effusion-symptoms-causes-treatments.

[48] Z. Cheng, Y. Lu, Q. Cao et al., "Clinical features and chest CT manifestations of coronavirus disease 2019 (COVID-19) in a single-center study in Shanghai, China," American Journal of Roentgenology, pp. 1-6, 2020.

[49] M. J. Choi, Y. S. Lee, J. Y. Lee, and K. S. Lee, "Novel influenza A (H1N1) virus infection in children: chest radiographic and CT evaluation," Korean Journal of Radiology, vol. 11, no. 6, pp. 656-664, 2010.

[50] R. M. Burke, C. M. Midgley, A. Dratch et al., "Active monitoring of persons exposed to patients with confirmed COVID-19 - United States, January-February 2020," Morbidity and Mortality Weekly Report, vol. 69, no. 9, pp. 245-246, 2020. 